\title{
Hafez's hermeneutic approach toward the formation of a character named Rend
}

\author{
Mohammadreza Zaman Ahmadi \\ Literary Thoughts Academic Journal Persian Literature Department, Islamic Azad University, Arak Branch, Iran
}

Email address:

m_zamanahmadi@iau-arak.ac.ir

\section{To cite this article:}

Mohammadreza Zaman Ahmadi. Hafez's Hermeneutic Approach toward the Formation of a Character Named Rend. International Journal of Literature and Arts. Vol. 1, No. 3, 2013, pp. 31-35. doi: 10.11648/j.ijla.20130103.12

\begin{abstract}
The text makes an interaction between the writer and the reader, the reader's understanding of a text in different historical periods is one of the methods used to interpret a text in the hermeneutic approach. Iranian mystic literature serves as cradle for the complexity and mysterious nature of textual meaning(s). Hafez, the great Persian sonneteer is one of the interpreters of textual meaning by creating different characters in the utopianistic realm of his poems, and introducing a new worldview to the readers. In the present study the writer seeks to examine and analyze Hafez's attempts in his hermeneutic reading and his formation of characters named Rend and Pire Moghan based on the texture of his poems. The writer believes that Hafez considers the character - Rend - regarding to its negative meaning, as an interpretation to indicate the dualistic nature of the universe in his poems, because it seems that Rend is closer and compatible to the two - dimensional nature of man. Through his hermeneutic reading on Rend, Hafez gives the term a determined concept to match the paradoxical concept of conflicting nature of man.
\end{abstract}

Keywords: Hermeneutic, Hermeneutic Reading, Hafez, Rend, Conflict

\section{Introduction}

A poet's/a writer's encounter with texts and related words used in the preceding texts, along with the impact of the text on him/her can create new text, that by itself may provide unexpected texts for the next readers. The new interpretations and readings on a text are included within the realm of hermeneutic while hermeneutic, the study of interpretation in course of its development has experienced different steps; Reader's Response Theory is considered as the newest hermeneutic theory, it argues that the reader's response gives life to a literary text just by his reading; in fact, every text, without being the subject of reading, has no effect/action, and that all the diction, at the outside, seems to be a series of physical signs on pages, in this case, they are like a stone wall signifying no sense. (Seldom)

Every text is effective just due to its readers, and every reader, based on his/ her time, language, situation and thoughts takes a unique interpretation [7].

Hafez is a typical poet who presented a different reading of some derogatory words by means of rereading and reading differently the classic texts, read by some other critics, so that the concept of one specific word within the contexts of Hafez's poems has perfectly changed, and the new concept is conveyed to his proceeding readers through his art of poetry.

Rend and Pire Moghan are two words selected by Hafez in the $8_{\text {th }}$ century which in the present study are examined as a symbol signifying Perfect Man. The purpose of the study here is to assess Hafez's hermeneutic reading on the above mentioned words of which, according to the poet's worldview, two different concepts are rendered. Consequently, the present study begins with the question:

What can be Hafez's hermeneutic reading on the new and different sense of Rend and Pire Moghan?

Regarding the review of literature and concerning Hafez's thoughts and the meaning of Rend and Pire Moghan, there is a plenty of books and essays including an essay by [8], entitled “The Study of Hafez's Addressees in the $8_{\text {th }} \&$ the $9_{\text {th }}$ centuries Based on the Literary History of Hermeneutic Approach." In this work Fotuhi deals with that type of reading that the readers open on Hafez s speech through his poems. But, in fact, there is no other book or article directly working on the very specific reading of Hafez's himself on the texts composed before him and on the particular meaning of rend and Pire Moghan. The methodology practiced here is that of analytic - inferential adapted to hermeneutic approach. 


\section{Methodology}

\subsection{Hermeneutic Reading on the Words: Rend \& Pire Moghan in the $8_{\text {th }}$ Century}

Hafez, by addressing himself as a reader, induces a hermeneutic reading of Rend in his poems. He sets himself in front of the works and poems composed in the previous centuries, and with the consideration of some factors like mystical thinking, socio - cultural environment, language, customs, and etc. renders an inventory interpretation, and concerning the role of man on the vast of universe forms his own understanding of the word, Rend, for:

Besides the unconscious aspect of any artistic work, which, to many critics, takes a greater role than the element of consciousness in the formation of work(s), some other factors such as socio - cultural environment, language, customs, and etc. unexpectedly leave their impacts on the work and its creator [1].

Thinking about the universe and the isthmus state of man makes Hafez improve the meaning(s) of Rend. In fact, hermeneutic reading is such that

The interpreter has some personal presupposed truths of his own with which changes the words and their corresponding meaning(s) in agreement with his own perception on ad understanding, and finally confirms that interpretive meaning which is ideologically stimulated and supported[8].

On the subject of Rend, it is notable that the word signifies a series of different meanings, and most of them are derogatory in their sense. Sometimes in its meaning it may stand for heedless, rude, traitor, voluptuous, inferior, drunkard, or signify some apparently positive, though actually negative words like shroud, intelligent, aware. Through cultural - literary history of our nation, Rend, in its meaning(s) has undergone three phases of change: The negative, the positive, and again restoration of the negative phase.

A. The negative phase: In this stage Rend signifies quite a negative and inappropriate meaning.

B. The positive phase: As literature gets closer, in its nature, to mysticism, the derogatory meaning(s) of the word are replaced by the positive ones, a change which is vividly reflected in lyric poems, especially in earthly and metaphysical sonnets.

Attributing Rend to somebody represents a man of perfection or semi - perfect man bestowed with some features of a great man like a man of love, freedom, honored, a brave heart, a holy spirit, and finally a semi god. Most of the texts in mysticism, either in prose or verse, particularly metaphysical sonnets contain such a multidimensional figures whom in one word are called by the name of Rend. Unlike any other writer/critic, Hafez's approach to the term, Rend, is quite different because to him achieving the name is the most wanting ideology, so much so that he calls his art and his poetic school that of Rend and Rend loving.

C. The restoration phase of negative meaning: After
Hafez and through the proceeding centuries we witness that Rend in its meaning is restored to the negative phase, so that now it signifies highly derogatory sense, it is interesting that the Persian speakers in India use the term for homosexuals, and in term of its modern practice in Farsi it connotes opportunist, time - server, and conservative [5].

It is worth noting that Hafez has been aware of the two extremes of meaning, both the positive and the negative, but it is his artistic innovation to derive these two words, Rend and Pire Moghan, from the previous texts, and use them in his works in accordance with his own ideology and the isthmus state of man.

Among the Persian poets, Sanaye was the first to apply Rend positively in his book of verse, so the initial trail of Rend as conceived by Hafez can be found in Sanaye's poems wherein the meaning is tinged with qualities such as kharabat , wine - worshipping, and drunkenness, and in fact, he goes so far that he considers drunkenness as the ideal manner of behavior.

Khayam in his quatrains also makes use of the term, Rend, to convey the sense of heedlessness, recklessness and shrewdness

To Attar Neishabori Rend is equal to a heedless man, lover, a wine worshiper, homeless, drunkard, and mendicant. In one of his sonnets figure he was described as:

end has got a negative personality, who is always drunk, unwise, and seeks to win the Beauties, of course, opposes any fame and stoicism.

In Salman Savoji's poems, there is an honored man, and he has so much in common with Hafez's Rend.

In fact, Hafez applies the words Rend and Pire Moghan as signifiers to signify two determined signified. Signification is of two types:

Determining signification: Here the user uses the signifier to refer to specific signified/sense. The meaning is fixed to the determined signifier, since it is used to associate one specific meaning, not to reflect a series of different meanings.

Determining Signification: The word is used, out of its frequented application, to signify specific meanings. Such a meaning is fixed and determined, that is, there is a one to one association between the signifier and the signified(s). [11].

\subsection{The Signifier Classified into Five Categories}

1 Specified signifier: It signifies just one single meaning

2 Common signifier: It signifies so many real meanings.

3 Transitional signifier: The real meaning is turned into anther meaning with keeping the relevance between the initial and the second meaning, it means, the meanings need not to be too much opposite.

4 Improvisator Signifier: The first meaning is changed into another meaning without keeping the 
relevance between these meanings.

5 Real and unreal: The signifier, in addition to its surface meaning, connotes the second unreal meaning. (Ibid, 31)

According to the above classification Hafez plays with the words Rend and Pire Moghan as transitional signifiers for the negative associations like rude, wine - worshipper, heedless, mean, and deceiver which are turned into the positive connotations such as large - hearted, honor, love, mendicant, etc. It is noticeable that the two extremes of meanings are read and understood in the word. The same duality of signified is reflected in the structure of Hafez's poems. In fact, the structure is conceived as "The linguistic environment dominating speech" [11] and linguistic structure is signified:linguistic environment of a language, that is, the grammatical and conceptual relations of a language with the other speech units or text. (Ibid, 212)

The main reason to apply Rend conveying the opposite connotations was due to the is thmusstate of man which depicts the internal or existential conflict of him. In other words, the hermeneutic reading of Rend helps the poet to render a new concept, signifying a perfect man, and put it in opposition to that traditional negative meaning.

last night I heard angels knocking at the tavern's door,

They Kneaded the clay of Adam and molded a cup

the inmates of the angelic shrine of mystery and chastity

Drank intoxicating wine with me, earthly one

Here is an allusion to the collection of "The Clay and Man's Heart," in which the clay is mixed with the wine of love (connoting the Holy Spirit and Divine Blast) and forms a paradoxical mixture of love and the Farvadin vessel of clay. As we read in the following, there is no harmony between this celestial and that diabolical, and the clash between them seems a consistent one:

This internal conflict justifies the sophistic/mystic manner, for all man's attempts, and his premature death, etc. reflect his demand for the invisible, or the need of the invisible man who tries to escape from his earthly existence; even he wishes to fly up as an encaged bird and direct his way toward lily's home and to embody the idea that" the earthly body can ascend to the skies by means of love", If the internal conflict ends in the triumph of evangelic forces, then in the world of reality there would be no clash of interests for man sees the unreal nature of these worlds and quit any demand/pretension on the unreal. In conjunction with forgetting his paradise dimension, the hallucination of wining the personal and social games makes man to ignore his inherent pain and suffer, and so gradually the superficial benefits / interests overcome the true ones, therefore, he will be entangled in the trap forever:

You are being addressed from the pinnacle of heaven;

And I knew not what has cast you into this trap.
It is right to state that the comfort and the peace of angels and animals is due to their one- dimensional existence and the pain and suffer tinged with man's nature is because of his multidimensional creation, and its isthmus state dangling between the extremes of angels on one side and animals/beasts on the other side" [2].

Maybe "certainly we have created man to be distress"(holy Quran, surah xc -Balad, the city) approves the same idea. Based on this deep - structured meaning Pire Moghan/Rend in the context of Hafez's poems mirrors man of sublimity or celestial man, and the conflict between Rend and ascetic and sufist is computable to the contrast of man and angels in heaven. In other words the very meaning which Hafez sets up by means of Rend associates a hero that as the lord of creation and the lord's caliph/successor is reproached by the angels, and the deceit rooted in self conceit of his prayers/worship is so much amplified that angels blame God the lord at the time of creation.

And when your lord said to the angels, I am going to place in the earth a khalif, they said: what! Wilt thou place in it such as shall make mischief in it and shed blood, and we celebrate Thy praise and extol Thy holiness? He said: Surely I know what you do not know (Holy Quran, surah II- the cow)

There are asceticism, haughtiness, prayer, intoxication and need for me

Let us see which of these received your favor

As much the angels were blind to whatever the Lord did teach Man at the time of creation, the ascetic is ignorant about Rend and his worldview and knows nothing of the secrets lying behind the stage, a fact which reveals the concept of Rend in the following verse line of Divan (the collection of Hafez's sonnets)

Ask the drunken knave the inner secret behind the veil,

For, an eminent ascetic is in no position to answer.

and:

The outward-worshipping ascetic is not aware of condition,

And whatever he says about us, can't be offensive

So out of the deduction theory and the necessity of understanding and explanation the reader figures out what the speaker meant through his words[11], a technique which is practiced by Hafez in his poems: The why that the clad of wool, whose sternness and bad temper is due to their rigid asceticism, are unaware of love is that they reject the acceptance of wisdom, in fact, angels are all of reason and mind, so, only the paradoxical nature of man which is bestowed with both soul and body. Although from Hafez's viewpoint the hypocrite ascetic / hermits of hypocrisy not only have not kept the divinity of the skies, but also have descended to the world of brutality.

It is understandable that such a dissention toward brutality keeps man away from his paradoxical nature and never leads him to Rend and his mannerism.

Love is a task that requires guidance. 
To explain why ascetics never stop blaming Rends, Hafez argues that the angelic asceticism is obligatory, and so they are unaware of the blessing of love given to Adam/Rend.

Go away o hermit, and cavil not at dregs-drinkers;

For we were given nothing but this gift since eternity

O sage, cavil not at me for roguery

The main cause of angels hatred to man comes from the authority of man as the loved of creatures, a fact which is not bearable at all to angels concerning their seven thousand years of worship/worshiping God the lord; of course it is the lord who is the great judge:

$\mathrm{O}$ ascetic, your prayer produces effect,

My nightly intoxication and supplications.

There we are, the ascetic and chastity;

Let the friend choose one of us

Consequently and based on all the above mentioned reasons:

Hafez's art cannot be considered as his preference of either extremes of man's isthmus state. Justice is not the leading cause, too. In fact, his art reflects the spiritual description and interpretation of man raised to this peculiar state the dualistic and ambivalent nature of the poet's character, in our eyes derived from Hafez's sincerity in his confrontation with his own nature as man. (Purnamdarian, $1382,8)$

In terms of Hafez's mystic - interpretive reading, Rend's ideology contains the following features; if the term sounds to be an umbrella term, signifying a miscellaneous meaning it is all because of the poet's touches on the word and the meaning it signifies, so that we find a direct relation between the word - Rend -and all the new meanings it reveals. As Nasri states:

The words are coined based on the essence of the objects, not the totality of their features and effects. Though these features have no hand in the meaning of the object, they have a reference to the essence. (Nasri,1381, 50)

1 - Slyness/Rendi is an eternal destiny

O sage, cavil not at me for roguery and ill-fame;

For, this has been my share in the court of fate.

2-Rend loves happiness and joys

$3-\mathrm{He}$ is a big drinker and pub - goers

4- He is ogling and eyeing up mistresses

$5-\mathrm{He}$ is against resentence and devotion

6- He is in rivalry with asceticism and ascetic

7- He defies hypocrisy and deceit

8- He has nothing to do with conservatives

What business has a world-burning rogue with prudence?

It is the realm's affaires that need reflection and deliberation

$9-\mathrm{He}$ is calendar/mendicant

$10-\mathrm{He}$ is a lover
11 - He never cares for fame

12 - To him Rendi/slyness is hardly affordable

To secure love and roguery seemed an easy task at first,

But at last my soul was burnt in obtaining these virtues

13 - Rend looks like a tramp and is careless to positions

14 -Spiritually he is heightened

15 - Constantly asks for the Lord's blessing and his salvation

The ascetic who was proud did not safely cover the path,

Whereas the knave found his way to the house of safety in his supplication.

Pinpointing all the corresponding characteristics of sly/Rend within the structure of his art, Hafez deals with the fields like: ethics, theoretic philosophy, modern politics, and scientific philosophy. In his ideology the supremacy the internal hero leads to getting control over all internal and external anti - heroes. While his contemporary sophists and courtly ascetics deceitfully wear the mask of dishonesty and Sufism to be able to stand against Hafez's Pire Moghan, Rend is quit sincere and honest, conceals nothing even in his name which reminds of Adam who is interlinked with the Lord's essence. Yet he calls himself "Mogh", signifies a sinner; the contrasting elements of his name not only indicate his paradoxical existence, which stands for the essential disobedience of Man, but also reflects his abstinent from hypocrisy.

I am a vagrant, wine-bibber, an ogling rogue,

Who exists in this city that does not resemble me?

O Hafez, don't expect rectitude, repentance and purity from us,

For, no one has seen expediency from a rogue, a lover, or a madman

And finally he confirms that it is not possible to pass the way to God the lord by oneself except to receive his mercy to get the direction.

O Hafez, spend not your secure days in reproach.

A lover said:"to these two you serve as a slave“"

(Ibid, 282)

\section{Conclusion}

In this study, I attempted to examine Hafez's hermeneutic approach in the formation of sly/Rend. By choosing the term - Rend - from the classic works where it signified both positive and negative meanings, since it is an appropriate word presenting the dualistic nature of man. In fact, Hafez, throughout his hermeneutic reading coins the term Rend based on a determined sense to be more identical to the paradoxical state of man. In this regard, it can be note that Rend is the only word which has the 
potential of conveying the abovementioned state, that is, concerning it's polarized meaning, so, it perfectly reveals Hafez's worldview about the creation of man, Adam and his contrast with Satan and angels in heavens and also reflects the contrast between the lover's slyness and the asceticism of sophists of the time.

\section{References}

[1] Eslin, Martin\& Shaba, M,2000.The World of Drama. Translated: 2nd edition, Tehran: Hermes puplication

[2] Purnamdarian, T,2000. Lost on the Coast. 1st edition, Tehran: Sokhan puplication.

[3] Hafez, Shamsedin, M ,1994.Dyvane Hafez. 14th edition, Tehran: Eghbal puplication.

[4] Khoram shahi, B ,1998.Hafez nameh.12th edition, Tehran: Elmi Farhangi publication.
[5] Dadbeh, A ,1996. Hafez pageuhi. Shiraz: Hafezshenasi Center publication.

[6] Seldon, R and Vidson ,P,1995. Guide to Modern literary Theory. Translated: Abas Mokhber. 2nd edition, Tehran:, Tarhena puplication.

[7] Shayeganfar, H,R.1998. literary Criticism 1st. edition, Tehran: Dastan publication.

[8] Fotuhi, M and Vafaie, A.2006. Study on the Readers of Hafez throngh the 8th \& 9th century, Based on History of Hermenutic. Quarter Literary Critices Second year, No, 6, PersianLiterature Research Center, ,Tarbiyat Modares university.

[9] Mulavi, G.M.1988 .Shams Sonnets. Tehran: javidan puplication.

[10] Mulavi, G,M.1990. Masnavi Manavi. Tehran:negah puplication.

[11] Nasri, A.1999. Text Secret. 1st edition, Tehran: Aftabelosehe puplication. 